\title{
Nicotine Activity on Healthy Oral Cells and Pharyngeal Tumor Cells
}

\author{
ADRIAN SITARU ${ }^{1 *}$, ADELINA CHEVERESAN ${ }^{2 *}$, VLAD LAURENTIU DAVID ${ }^{2 *}$, RAZVAN SUSAN ${ }^{2 *}$, MONICA SUSAN ${ }^{1}$, DANA STOIAN ${ }^{1}$, \\ FLORIN SZASZ ${ }^{2}$, NICOLAE BALICA ${ }^{1}$, MARIOARA POENARU ${ }^{1}$ \\ IVictor Babes University of Medicine and Pharmacy, Faculty of Medicine, 2 Eftimie Murgu Sq., 300041, Timisoara, Romania \\ ZUniversity of Oradea, Faculty of Medicine, 101 December Sq., Oradea, Romania

\begin{abstract}
A number of studies highlight the harmful effects of smoking and the extremely serious consequences of the majority of compounds found in cigarettes and cigarette smoke. Of these, nicotine has attracted attention due to the suspicion of a carcinogen compound. The present study investigated the effect of nicotine on primary gingival keratinocytes but also on pharyngeal tumor cells, by evaluating viability and apoptotic processes.
\end{abstract}

Keywords: nicotine, cells, keratinocytes, pharynx, tumor

Smoking, implicitly tobacco, is associated with the occurrence and development of different types of cancer. It is a carcinogen known for multiple parts of the human body, such as: respiratory, digestive, excretory systems airway and respiratory tract, gastrointestinal tract and related organs (mouth, pharynx, larynx, lung, esophagus, stomach, pancreas, liver, colon, etc.). However, organs that are directly exposed to cigarette smoke have been shown to be more prone to carcinogenesis. The two main classes of compounds found in cigarette smoke are: (i) the particles, represented by tar (benzopyrene and nitrosamine supplier) and nicotine, and (ii) gases, mainly carbon monoxide [1]. In recent years, human nicotine toxicity has been increasingly pronounced due to the appearance on the market of a wide range of nicotine products. These include both the products intended for the replacement of the classic cigarettes - the forms of tobacco that do not smoke, the electronic cigarettes, etc., as well as the products that are intended for people who want to quit smoking - chewing gums, patches, etc. In the literature it is specified that the lethal dose for adults is up to $60 \mathrm{mg}$, a value that is worrying considering that it is the equivalent of five cigarettes or $10 \mathrm{~mL}$ of nicotine diluted solution [2]. Nicotine uptake can occur in the buccal cavity, nasal cavity, pharynx (nasopharynx, oropharynx and hypopharynx), larynx skin, lungs, bladder, and gastrointestinal tract, absorption depending on $\mathrm{pH}$. In the ionized state in acidic environments, nicotine slowly crosses biological membranes. The absorption of nicotine in the lungs is rapidly (it occurs at a rate similar to that after intravenous administration) due to the large surface area of the pulmonary alveoli and the $\mathrm{pH}$ of about 7.4 while at the stomach level, the absorption of nicotine is reduced due to the acidic $\mathrm{pH}$ of the gastric juice, but it is well absorbed in the intestine due to the alkaline $\mathrm{pH}$ and the large absorption surface $[3,4]$. Nicotine exerts its cellular functions through nicotinic acetylcholine receptors which are homomeric or heteromeric pentamer proteins located in the central nervous system and neuromuscular junctions and binding of nicotine to these receptors results in the release of dopamine with consequences that lead to addiction [5]. Due to smoking, besides the lungs, the upper aero-digestive tract is affected, with very serious long-term consequences that result in the occurrence of oral and pharyngeal cancers, mainly squamous cell carcinomas [6]. These have become a major health problem in recent years, both from the point of view of the patient's suffering and from the socio- economic point of view. Oral tumor disease is more common among men who usually come from poor social backgrounds, especially Asia and Europe, Southeast Asia is famous for the deaths that result from this disease and accounts for half of the number of deaths worldwide [7, 8]. Regardless of the form of presentation, the use of tobacco is the main factor that leads to the occurrence and development of oral cancer, being associated with a percentage of $90 \%$ among males and $60 \%$ among females [9].

Known as squamous cell carcinomas, the forms of oral cancer differ depending on location. There are two types of loss of suppressor gene function, loss of function due to methylation of the promoter region of genes leading to cancer occurrence in the oral cavity and allelic loss leading to pharyngeal or laryngeal cancer [10].

The study of the mechanisms of pharyngeal and laryngeal cancer development is very important and topical. The first step in elucidating the different mechanisms is the use of cell cultures. Healthy and tumor cell lines help to track behavior in the presence of different factors and offer the advantage of selective use. In the present study, were selected two cell lines, human gingival keratinocytes and pharyngeal carcinoma, and was assessed the behaviour of cells in the presence of nicotine with the help of cytotoxicity and cell proliferation assays.

\section{Experimental part}

Materials and methods

Reagents and cells

The following human cell lines were utilized in the current research: Primary Gingival Keratinocytes (ATCC $®$ ) PCS-200-014 ${ }^{\mathrm{TM}}$ ) and Detroit 562 (ATCC $®$ CCL-138 ${ }^{\mathrm{TM}}$ ) - cell line derived from metastatic site, pleural effusion. The cells were purchased from the ATCC (American Type Culture Collection). The healthy cells were cultured in Dermal Cell Basal Medium as recommended by the manufacturer and as described in the literature [11] while tumor cells were cultured in Eagle's Minimum Essential Medium supplemented with fetal bovine serum $10 \%$. During the cultivation period the cells are incubated at $37^{\circ} \mathrm{C}$ and the atmosphere with $5 \%$ carbon dioxide. All the suitable reagents for cell culture were purchased from Sigma Aldrich and ATCC. Cell proliferation kit I (MTT) and nicotine were purchased from Merck (Germany) and Annexin V-FITC kit from eBioscience (Austria). The concentrations of nicotine were between 0.25-15. 
Viability assays. Viable cells were evaluated at the starting of cell plating and in the period of cell growth at every passage before the experiment. Cells were culture until they reached at least $80 \%$ confluence. Baseline determinations of viable cells were realized at the beginning of each test or at $0 \mathrm{~h}$ and then at different time points: $24 \mathrm{~h}$, $48 \mathrm{~h}$ and $72 \mathrm{~h}$. Cell counting was done with Trypan blue on a Countess ${ }^{\mathrm{TM}}$ II Automated Cell Counter (Thermo Fisher Scientific, USA) and the determinations were realized in triplicate.

MTT technique was used, according to the protocol presented in the literature [12, 13], to evaluate cell viability after stimulation with different nicotine concentrations.

Apoptosis and necrosis. Annexin V/PI apoptosis assay was utilized and briefly the protocol suppose: $4 \times 10^{5}$ cells/ well (Detroit562) were seeded into 6-well plates, different concentrations $(0.25-15 \mu \mathrm{M})$ of nicotine were added, after one day of treatment, cells were washed with PBS, centrifugated, resuspended in media, a mixture Annexin $V$ Binding Buffer and FITC-conjugated Annexin V was added to cell suspension, plates were incubated and finally Propidium lodide solution was added. The plates were examined by flow cytometer.

\section{Results and discussions}

The relative change in the viability of the cells used in the present study was evaluated starting with the initiation of cell cultures (at least $80 \%$ confluence) and for three consecutive days (fig. 1).

Data obtained showed a high cell viability, between 82$97 \%$, as follows: primary gingival keratinocytes at the beginning presented a percentage of $89 \%$ while after $72 \mathrm{~h}$ the percentage increased to $97 \%$; tumoral cells (Detroit 562 ) initially presented a viability of $81 \%$ after 2 days the viability was $88 \%$ and after three days $92 \%$.

Following the stimulation of cells with different nicotine concentrations the viability of the cells was significantly influenced, as can be seen in figures 2 and 3. At $24 \mathrm{~h}$ poststimulation, at low concentrations of nicotine no significant difference between the percentages of viability (with or without nicotine) was recorded: keratinocytes viable cells were decreased from 93 to $91 \%$, while Detroit 562 cells were decreased from 96 to $90 \%$. In the case of higher concentrations of nicotine utilized the viability percentage, at 24h post-stimulation, were significantly modified: PGK viability was $47 \%$ while Detroit 562 viability was $31 \%$.

The effect of nicotine on Detroit 562 pharynx cancer cells apoptotic status was pronounced. At $15 \mu \mathrm{M}$ it was observed an important increase of death cells (72\%), as can be seen in figure 4 .

Cancer of the oral cavity and respiratory system has a strong connection with smoking and cigarette smoke. A number of studies have been performed to evaluate the effects of nicotine on different tumor cells. Lee and co-
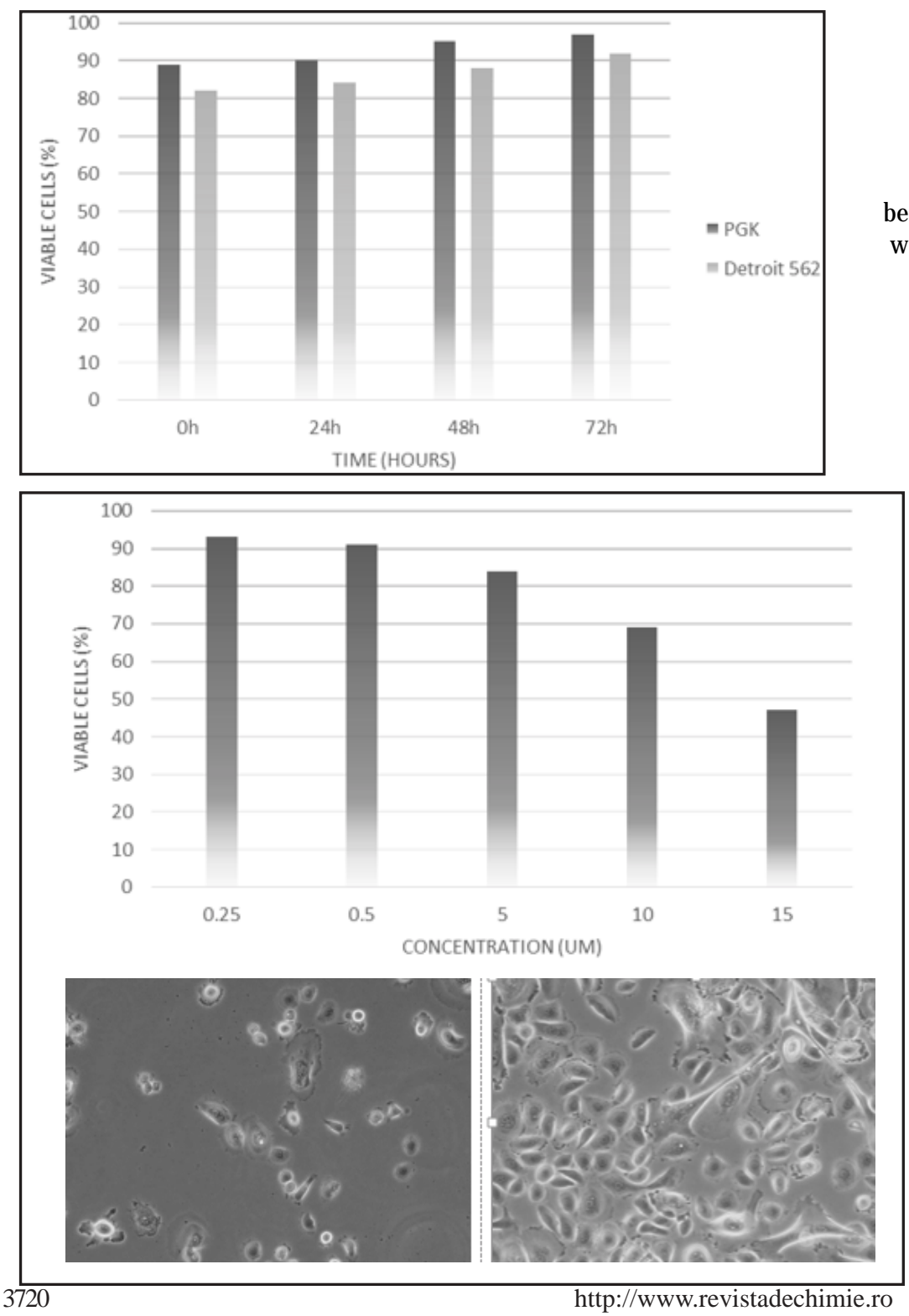

Fig. 1. Baseline determinations of viable cells before the experiments. The number of viable cells was realized with Trypan blue on a specific device
Fig. 2. Primary keratinocytes viability in the presence of different concentration of nicotine determined by MTT assay. 

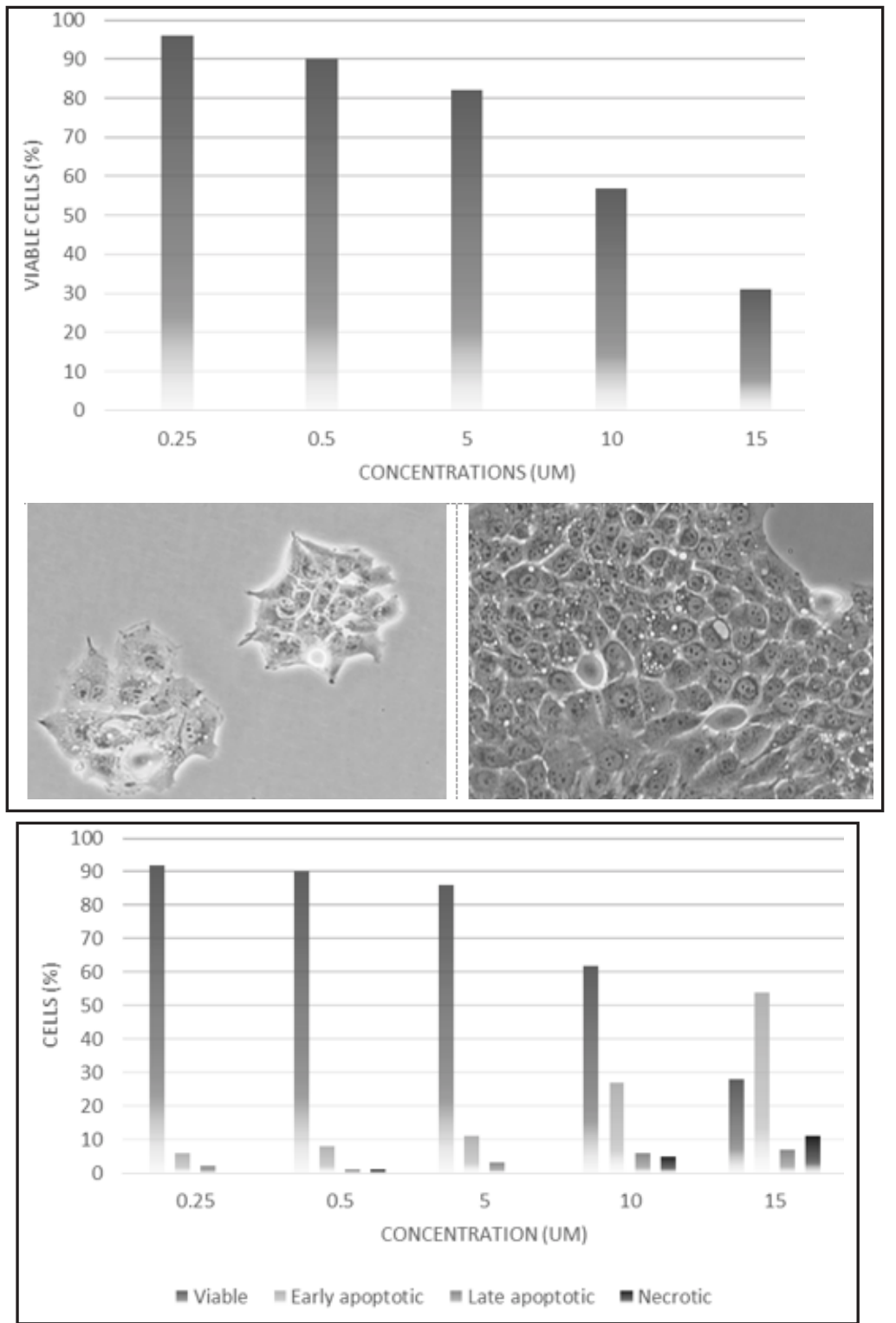

Fig. 3. Pharynx cancer cells (Detroit 562) viability in the presence of different concentration of nicotine determined by MTT assay.
Fig. 4. Pharynx cancer cells (Detroit 562) apoptotic cells in the presence of different concentration of nicotine determined by Annexin V/PI apoptosis assay workers pointed out that nicotine stimulation of immortalized keratinocytes and HN4 and HN12 tumor cells strongly influences epithelial cell proliferation, delaying cell cycle progression [14]. Some authors have exposed immortalized keratinocytes and pulmonary cells to cigarette smoke and vapour produced by electronic cigarettes, analysing the viability, morphology and proinflammatory activity. Their results show that vapours produced by electronic cigarettes are less toxic than cigarette smoke and in addition to the deleterious effect of different flavours and nicotine, single humectants can lead to the release of cytokines [15].

\section{Conclusions}

The results obtained in the present study contribute to the understanding the nicotine activity on the oral cells but also on the tumor pharynx cells. Nicotine exerts at certain concentrations harmful effects on the cells, destroys the healthy cells which has as a consequence due to the injury of the cells and the appearance of the precancerous lesions. In the case of a malignant disease nicotine can intensify the cellular manifestations and the results are negative for the recovery of the patient.

\section{References}

1. SHIMIZU, R., IBARAGI, S., EGUCHI, T., KUWAJIMA, D., KODAMA, S., NISHIOKA, T., et al. Int J Oncol. 54(1), 2019, p. 283.

2. MAYER, B. Arch Toxicol. 88(1), 2014, p. 5.
3. SANNER, T., GRIMSRUD, T.K. Front Oncol 5, 2015, p. 196.

4. NAKAJ IMA, M., YOKOI, T. Drug Metab Pharmacokinet. 20(4), 2005, p. 227.

5. DAVIS, R., RIZWANI, W., BANERJEE, S., KOVACS, M., HAURA, E., COPPOLA, D., CHELLAPPAN, S. PLoS One 4, 2009, p. e7524.

6. VAN DER WAAL, I. Med Oral Patol Oral Cir Bucal 18(1), 2013, p. e33. 7.J EMAL, A., BRAY, F., CENTER, M.M., FERLAY, J., WARD, E., FORMAN, D. CA Cancer J Clin 61(2), 2011, p. 69.

8. PETTI, S., MASOOD, M., SCULLY, C. PLoS One 8(11), 2013, p. e78999. 9. VISWANATH, A., KERNS, T.J ., SORKIN, J.D., DWYER, D.M., GROVES, C., STEINBERGER, E.K. J Public Health Dent. 73(4), 2013, p. 261.

10. SHIGA, K., OGAWA, T., KATAGIRI, K., YOSHIDA, F., TATEDA, M., MATSUURA, K., KOBAYASHI, T. Onclogy Lett. 2011, p. 238.

11. CORLAN, I.V., CHEVERESAN, A., BERCEANU VADUVA, D., NICA, C., FAUR, A., RUMEL, R.C., RAMONA AMINA POPOVICI, R.A. Rev.Chim.(Bucharest), 69, no. 10, 2018, p.2891.

12. ANDOR, B., TISCHER (TUCUINA), A.A., BERCEANU-VADUVA, D., LAZUREANU, V., CHEVERESAN, A., POENARU, M. Rev.Chim. (Bucharest), 70, no. 3, 2019, p. 781.

13. ANDOR, B., DANCIU, C., ALEXA, E., ZUPKO, I., HOGEA, E., CIOCA, A., et al. Evid.-Based Complementary Altern. Med. 2016, 2016, Article ID 7638542, p. 1-8.

14. LEE, H.J., GUO, H.Y., LEE, S.K., JEON, B.H., JUN, C.D., LEE, S.K., et al. J Oral PAathol Med. 34(7), 2005, p. 436.

15. CERVELLATI, F., MURESAN, X.M., STICOZZI, C., GAMBARI, R., MONTAGNER, G., FORMAN, H.J. et al. Toxico

\section{Manuscript received: 16.08 .2019}

